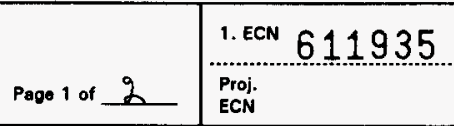

\begin{tabular}{|c|c|c|c|c|c|c|}
\hline \multirow{3}{*}{ 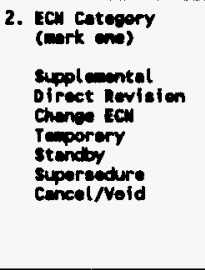 } & \multirow{3}{*}{ 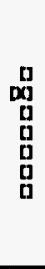 } & \multicolumn{2}{|c|}{$\begin{array}{l}\text { 3. orloinater'a Mewe, aremizotion, mII, } \\
\text { R.D. KECK, 15510, T4-20, 373- } \\
1768\end{array}$} & \multicolumn{2}{|c|}{$\begin{array}{l}\text { 3n. use nexuliteon } \\
\text { [X] yee [] no }\end{array}$} & $\begin{array}{l}\text { 4. Date } \\
\text { June 27, } 1996\end{array}$ \\
\hline & & \multicolumn{2}{|c|}{$\begin{array}{l}\text { 5. Project ritte/wo.Nert order wo. } \\
\text { SEISHIC FAN SHUTDOWN SYSTEM }\end{array}$} & \multicolumn{2}{|c|}{$\begin{array}{l}\text { 6. Dide./sva./Fac. Wo. } \\
\text { 234-5Z/99B }\end{array}$} & $\begin{array}{l}\text { 7. Approval oeei } \\
\text { SQ }\end{array}$ \\
\hline & & \multicolumn{2}{|c|}{ 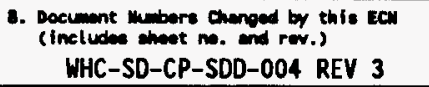 } & \multicolumn{2}{|c|}{$\begin{array}{l}\text { 9. Roleted ECN Mo(s). } \\
\text { NONE }\end{array}$} & 10. Related po Ho. \\
\hline \multirow{2}{*}{\multicolumn{2}{|c|}{$\begin{array}{l}\text { 110. Modification Hork } \\
\text { [] Yee (fill ave Bik. } \\
\text { 11b) } \\
\text { [X] Ho (M Blks. 11b, } \\
11 c \text {, idd) }\end{array}$}} & \multirow[t]{2}{*}{$\begin{array}{l}\text { 116. Work Package } \\
\text { Wo. } \\
\text { N/A }\end{array}$} & \multirow{2}{*}{\multicolumn{2}{|c|}{$\begin{array}{l}\text { 11c. Modification Werk Complote } \\
\text { N/A }\end{array}$}} & \multicolumn{2}{|c|}{$\begin{array}{l}\text { 11d. Restored to original condl- } \\
\text { tion (Temp. or stemey tew only) } \\
\text { H/A }\end{array}$} \\
\hline & & & & & & neer sigr \\
\hline
\end{tabular}

12. Description of Chenes

Design Basel ine Document: YES

Complete update of Rev. 3 for installation of new annunciator for seismic system disabled alarm in room 714, 234-52A.

For USQ see 96-11.

130. Justification (mork $\mathrm{cmo}$ )

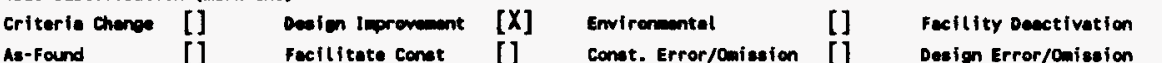

136. Justification Dotoile

Provide visual and audible alarm in new power control room with power fail alarm.

14. Distribution (include nem, MSIW, wh. of ceples)

RD KECK T4-20

DA CONNERS

T5-11

LE EDVALSON T5-48

DR GROTH T4-15

JP KING T5-51

AO Anderson T4-19

GA Glover T4-20

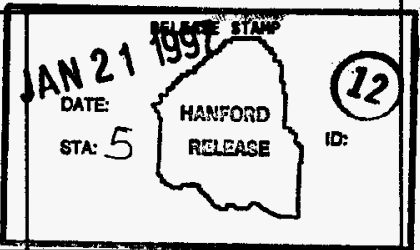

A-7900-013-2 (11/94) CEF095 


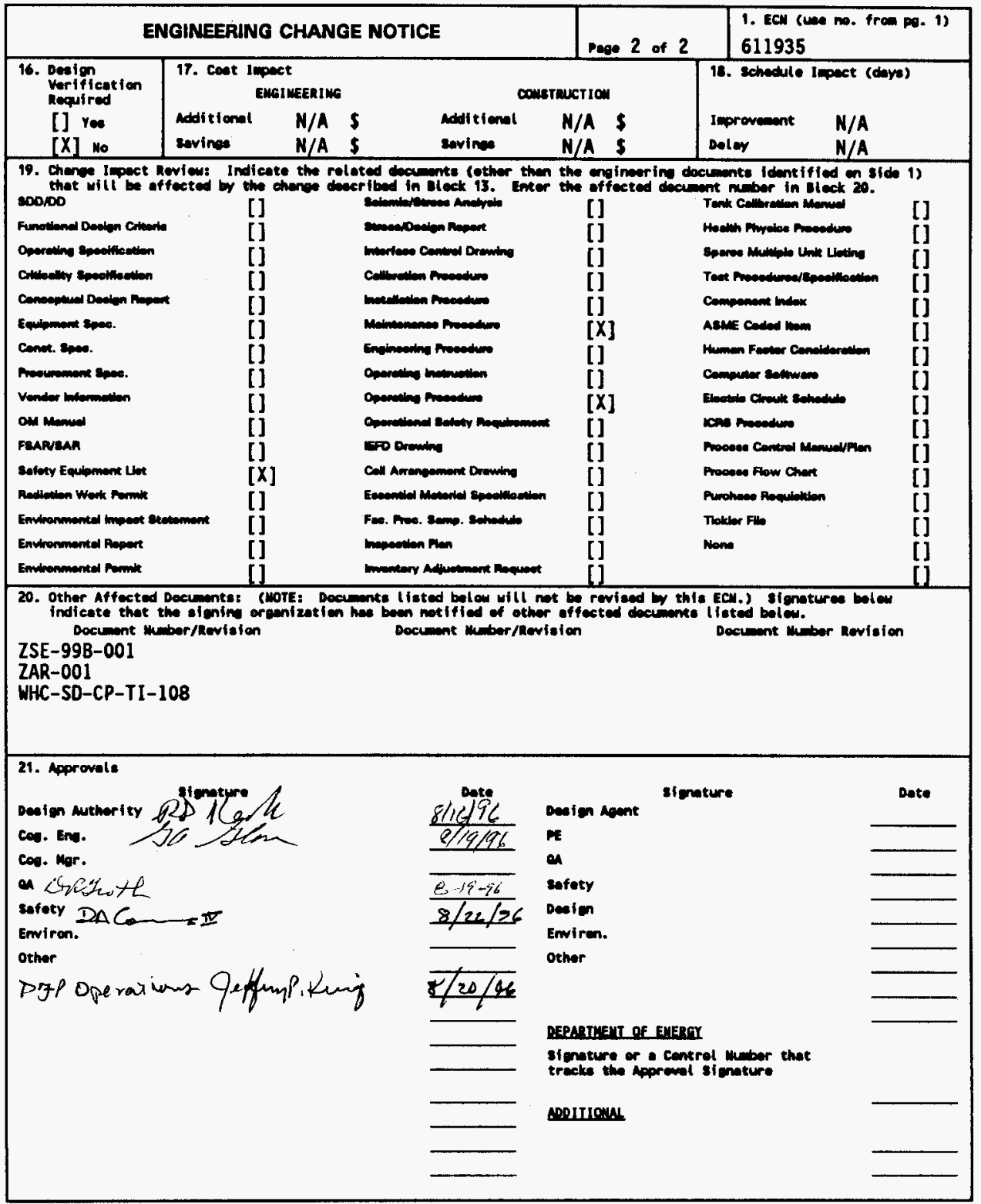




\section{Definition and Means of Maintaining the Supply Ventilation System Seismic Shutdown Portion of the PFP Safety Envelope}

R. D. Keck

Babcock and Wilcox Hanford Company, Richland, WA 99352

U.S. Department of Energy Contract DE-AC06-87RL10930

$\begin{array}{llll}\text { EDT/ECN: } & 611935 & \text { UC: } 515 \\ \text { Org Code: } & 15510 & \text { Charge Code: } & \text { K6001 } \\ \text { B\&R Code: } & \text { EW7002010 } & \text { Tota1 Pages: } & 17\end{array}$

Key Words: HVAC. Ventilation, Seismic, Shutdown, Authorization Basis, Safety Envelope, OSR

Abstract: The Supply Ventilation System Seismic Shutdown ensures that the 234-5Z building supply fans and the dry air process fans are shutdown following a seismic event. This document defines the safety envelope for the Ventilation System Seismic Shutdown and identifies the operability requirements, components, and procedures which ensure this safety envelope is maintained.

Westinghouse is a tradenark of Westinghouse Electric Corporation, Pittsburgh, PA

Ronan is a registered trademark of Ronan Engineering Company, Woodland Hills, CA

General Electric is a registered trademark of General Electric Corporation, Schenectady, NY

TRADEMARK DISCLAIMER. Reference herein to any specific commercial product, process, or service by trade neme, trademark, manufacturer, or otherwise, does not necessarity constitute or imply its endorsement, recommendation, or favoring by the United States Goverment or any agency thereof or its contractors or subcontractors.

Printed in the United States of America. To obtain copies of this document, contact: WHC/BCS Document Control Services, P.0. Box 1970, Mailstop H6-08, Richland WA 99352, Phone (509) 372-2420; Fax (509) 376-4989.
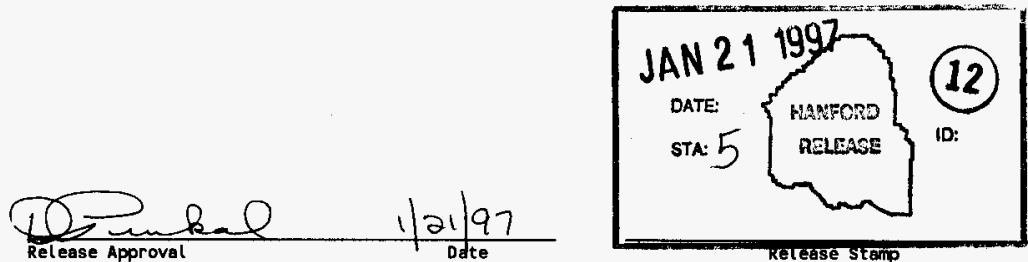

Approved for Public Release 
(2) Tite

Definition and Means of Maintaining the Supply Ventilation System Seismic Shutdown

Portion of the PFP Safety Envelope CHMYE COUIR.PL RECOPD

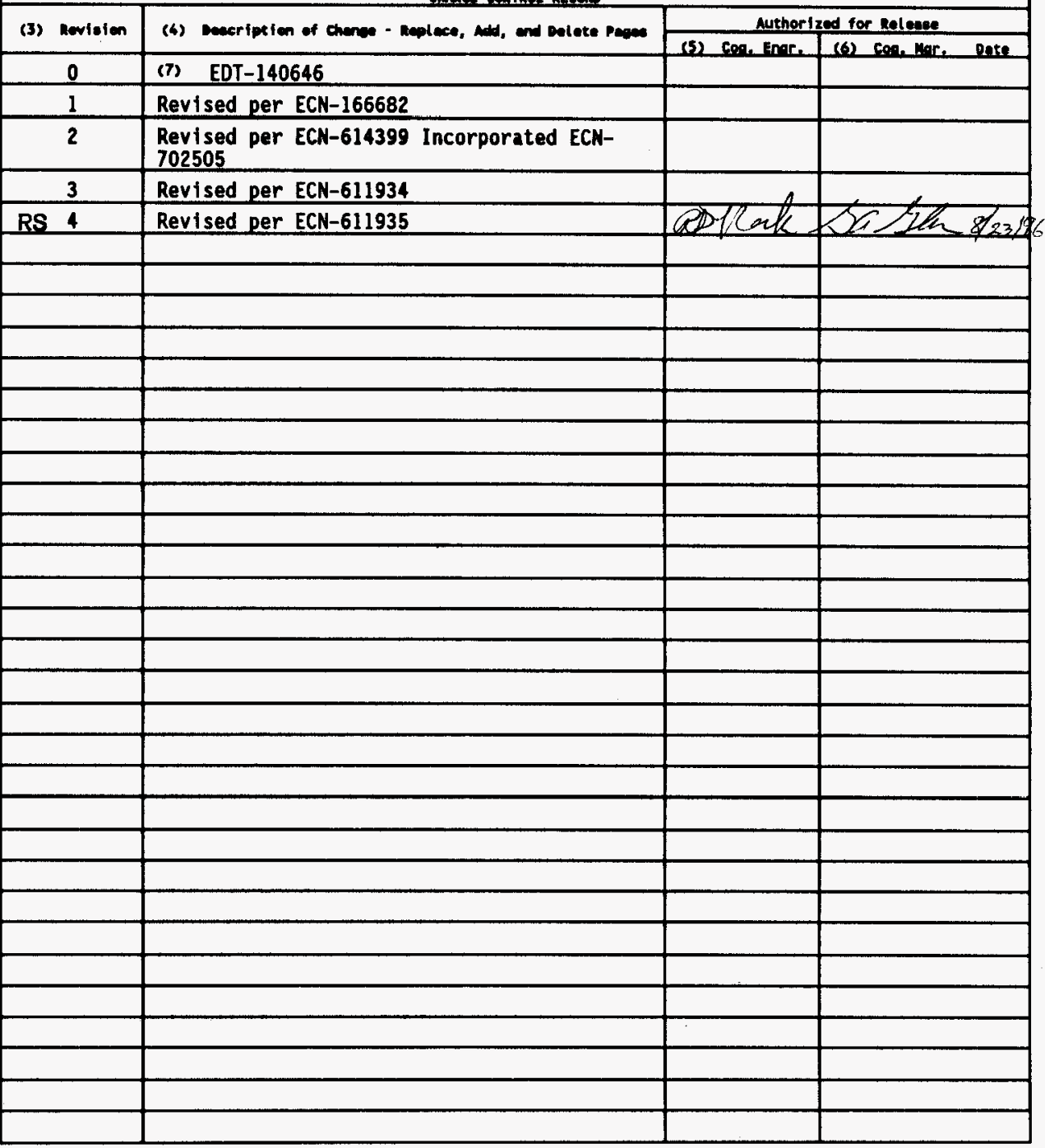




\section{Table of Contents}

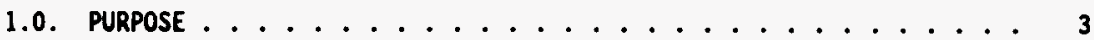

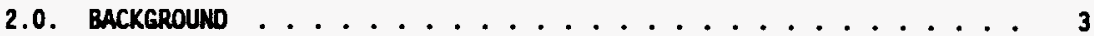

3.0. SYSTEM FUNCTIONAL REQUIREMENTS ............... 3

3.1. OSR REQUIREMENTS AND SYSTEM OPERATION ............ 4

3.2. OSR SURVEILLANCE AND RECOVERY ACTIONS . . . . . . . . . . 4

4.0. SAFETY ENVELOPE (SE) EQUIPMENT ................ 5

4.1. SELECTION OF SE EQUIPMENT . . . . . . . . 5

4.2. JUSTIFICATION FOR EXCLUSION OF EQUIPHENT FROM SE ...... 8

5.0. SAFETY ENYELOPE PROCEDURES ................. 11

5.1. SE ALARM RESPONSE PROCEDURE . ............. 11

5.1.1 ZAR-001, ANN-714 Panel Alarms ............ 11

5.2 EqUIPMENT MAINTENANCE AND REPAIR ............ 11

6.0. SAFETY ENVELOPE SURVEILLANCE REQUIREMENTS . . . . . . . . 11

6.1. SURVEILLANCE REQUIREMENT SR $3.2 .3 .1 \ldots \ldots \ldots \ldots \ldots$ il

6.2. SURVEILLANCE REQUIREMENT SR $3.2 .3 .2 \ldots \ldots \ldots \ldots \ldots \ldots . \ldots . \ldots 12$

REFERENCES ........................ 12

Appendix A - OSR Systems Compliance Sheet . . . . . . . . . . 13

Appendix B - Master Component Index Input List . . . . . . . . . 16 


\subsection{PURPOSE}

The purpose of this document is to record the technical evaluation of the Limiting Condition for Operation (LCO) described in the Plutonium Finishing Plant (PFP) Operational Safety Requirements, WHC-SD-CP-OSR-010, Rev. 0. May 1994, Section 3.2.3, "Supply Ventilation System Seismic Shutdown." This document, with its appendices, provides the following:

1. The system functional requirements for determining system operability (Section 3 ).

2. Evaluations of equipment to determine the safoty boundary for the system (Section 4).

3. A list of annotated drawings which show the safety envelope boundaries (Appendix C).

4. A list of the safety envelope equipment (Appendix B).

5. Functional requirements for the individual safety envelope equipment, including appropriate setpoints and process parameters (Section 4.1).

6. A list of the operational, maintenance and surveillance procedures necessary to operate and maintain the system equipment within the safety envelope (Sections 5 and 6 and Appendix A).

\subsection{BACKEROUND}

The 234-52 building in the Plutonium Finishing Plant (PFP) has been analyzed to determine the consequences of $a .20 \mathrm{~g}$ safe shutdown earthquake (SSE). WHC-SD-SQA-TI-013 Rev. 2, "Safety and Risk Assessment Technical Information to Support PFP Restart," concluded that the most serious spread of contamination from an SSE would occur if the building were pressurized by the main supply fans while the exhaust fans no longer functioned. In accordance with $\mathrm{HHC}-\mathrm{CH} 4-4-46$, section 9.0 , the supply ventilation system seismic shutdown system is designated Safety Class.

\subsection{SYSTEM FUACTIOUAL REQUIREMENTS}

The supply ventilation system seismic shutdown is provided to witigate the consequences of exhaust fan fallures during a seismic event which breaches the structural confinement barriers. On receipt of a signal from either of two accelerometers, the ventilation control circuits must remove electrical power from fans which may pressurize the building. Each accelerometer has two sensors with one mounted in each the east- 
west and north-south directions. A vertical sensor is not included'. Each accelerometer is set to actuate (open a circuit) if it detects an acceleration greater than $0.07 \mathrm{~g}$.

\subsection{OSR REQUIREMENTS MD SYSTEM OPERATION}

As specified in HHC-SO-CP-OSR-010, LCO 3.2.3, an accelerometer-activated system shall shut down the 234-5Z supply ventilation in the event of an earthquake greater than $0.07 \mathrm{~g}$. More specifically, the building supply fans and the dry air stage 2 process fans (supply fans) must be secured, preventing the pressurization of the building. Power is ramoved from the undervoltage coll of the circuit breaker for the supply fan motors. A detalled sequence of equipment operation is provided in Section 4.1. Exhaust fans and minor supply fans are also shut down by this system to provide an orderly shutdown of the ventilation system, but this function is not a safety requirement.

The supply ventilation system seismic shutdown is considered inoperable if it fails to shutdown the supply fans upon occurrence of a greater than $0.07 \mathrm{~g}$ seismic event. In the event that a seismic event is sensed by the power operator and the supply ventilation seismic shutdown system falls to shut down the supply fans, the supply fans will be shutdown manually using either the manual seismic shutdown switch (appendix A, required action A.1) or individual controls (appendix $A$, required action A.2). Although not required by the OSR, the operator should shutdown 234-5Z exhaust fans to maintain ventilation balance and avoid possible excessive differential pressures throughout the butlding.

\subsection{OSR SURYEILLANCE AND RECOVERY ACTIONS}

Annual functional testing of the accelerometer-activated shutdown is required. The LCO requirement specifies the $0.07 \mathrm{~g}$ acceleration at which the seismic shutdown is to occur, therefore a survelliance is also required to verify the caltibration of the accelerometer.

If the functional test or calibration have not been performed within the required interval or are unsatisfactory, the supply ventilation seismic shutdown system shall be considered inoperable. Operations will be liwited such that no additional plutonium is brought into the $234-52$ and $236-2$ butldings. If the

1 A vertical sensor was not included for the following two reasons. First, seismic analyses determined that building damage that would result in a loss of containment are caused by the horizontal components of earthquakes (URS/John A. Blume and Associates, Engineers, 1987, "Seismic (SSE) Evaluation for the 234-52 Building at the Hanford Site"). Second, tests determined that construction and general operating activities cause primarily vertical accelerations. Thus nuisance trips could be minimized without missing a potentially damaging earthquake by not including a vertical sensor. 
system falls the functional test or calibration, repairs shall be initiated within 24 hours of fallure. If the system is not returned to an OPERABLE condition within 10 days, the 234-5Z supply fans shall be shutdown or a written RECOVERY PLAN shall be initiated to remove DISPERSIBLE plutonium from the gloveboxes in 234-5Z and 236-Z.

Because the ventilation seismic shutdown system consists of two redundant channels of instrumentation, each capable of shutting down the buflding supply fans and the dry air stage 2 process fans (supply fans), the system shall be considered OPERABLE if at least one of the two channels is fully operational. This allows maintenance to be performed on one channel of the system while the other channel ensures compliance with the LCO. However, the ventilation soismic shutdown system is designed to operate under normal circuastances with both channels of instrumentation. Therefore, Plant Manager and PFP Safety approval is required for facility operation of wore than 24 hours duration with only one channel of the ventilation seismic shutdown system OPERATIONAL. The inoperable accelerometer channel wust be restored to an OPERABLE condition within 30 days. If the inoperable channel cannot be returned to an OPERABLE condition, the inoperable channel is subject to event categorization and reporting requirements of MHC-CH-5-8, Section 1.4 "Occurrence Reporting."

\subsection{SAFETY ENVELOPE (SE) EQUIPHENT}

\subsection{SELECTION OF SE EqUIPMENT}

The following discussion describes the function of the equipment which forms the supply ventilation system seismic shutdown safety envelope and the justification for including this equipment in the safety envelope. Most safety envelope equipment for this system is relied upon in the FSAR to function to mitigate the uncontrolled release of radioactive materials following an earthquake which involves the fallure of a physical barrier(s). The only exception to this is the "on-line/bypass" switches which indicate that the Seismic Shutdown System is not OPERABLE. (The information in parentheses indicates the location of the equipment on drawings $H-2-78073$ sheet $2, H-2-96422$ sheet 1 , and H-2-96436 sheet 4).

4.1.1 Accelerometers 1 and 2 (H-2-78073, sheet 2, 1 ines 54 and 60) and contacts ACCLRH1 and ACCLRH2 (sheet 2, 1 ines 51 and 57).

The accelerometers detect an earthquake greater than $0.07 \mathrm{~g}$ and initiate the actions required to shutdown the 234-5Z ventilation supply fans and dry air process supply fans. When an earthquake greater than $0.07 \mathrm{~g}$ has been detected, contacts ACCLRM1 and ACCLRM2 open. 
4.1.2 Relays K1, K2, K3, K4 (H-2-78073, sheet 2, Iines 51, 57, 52 and 58 respectively) and the associated contacts described below.

Relays K1, K2, K3, and K4 are normally energized. Following an earthquake of greater than $0.07 g$, relays $K_{1}, K_{2}, K_{3}$, and K4 are deenergized when contacts ACCLRM1 and ACCLRM2 open. Deenergizing relays $K 1, K 2, K 3$, and $K 4$ opens their associated contacts as described below.

- Contacts $\mathrm{K} 1-1, \mathrm{~K} 2-1, \mathrm{~K} 1-2$ and $\mathrm{K} 2-2$ (H-2-78073, sheet 2, Iine 2).

Contacts $K 1-1, K 2-1, K 1-2$ and $K 2-2$ are closed when relays $K 1$ and $K 2$ are energized. Deenergizing relays $K 1$ and $K 2$ opens contacts $K 1-1, K 2-1, K 1-2$ and $K 2-2$. Opening contacts $\mathrm{Kl}-1$ or $\mathrm{K2}-1$ deenergizes the undervoltage relays for supply fans $S 1, S 2, S 3$ and $S 4$. Opening contacts $\mathrm{Kl}-2$ or $\mathrm{K2-2}$ deenergizes the undervoltage relays for supply fans S5, S6, 57 and S8.

- Contacts $K 1-3$ and $K 2-3$ (H-2-96436, sheet 4, line 18).

Contacts $K 1-3$ and $K 2-3$ are closed when relays $K 1$ and $K 2$ are energized. Deenergizing relays $K 1$ and $K 2$ opens contacts $\mathrm{K} 1-3$ and $\mathrm{K2}-3$. Opening contacts $\mathrm{K1-3}$ or $\mathrm{K} 2-3$ deenergizes the $15 \mathrm{HP}$, stage 2 process fan associated with the electric air dryer unit located on the second floor adjacent to column C19.

- Contacts K3-1 and K4-1 (H-2-96422, sheet 1 , line 16).

Contacts K3-1 and K4-1 are closed when relays $\mathrm{K3}$ and $K 4$ are energized. Deenergizing relays $K 3$ and $K 4$ opens contacts $K 3-1$ and $K 4-1$. Opening contacts $K 3-1$ or $K 4-1$ deenergizes the $15 \mathrm{HP}$, stage 2 process fan associated with the steam air dryer unit located on the second floor adjacent to column C19.

4.1.3 Motor starter 3n in the electric air dryer control cabinet (H-2-96436, sheet 4, Iine 18) and assoclated 480Y, 3-phase contacts (H-2-96436, sheet 4, zone 6F).

Motor starter 3N is energized when the electric dry air systew is operating. Following a seismic event which initiates a ventilation shutdown, motor starter $3 H$ is deenergized when contact $\mathrm{K1-3}$ or $\mathrm{K2-3}$ opens. Deenergizing motor starter $3 H$ opens 480 volt, 3 phase contacts, which deenergizes the electric dry air, $15 \mathrm{HP}$, stage 2 process fan. 


\subsubsection{Notor starter 3n in the stean air dryer control cabinet (H-2-96422, I ine 16) and associated 480V, 3-phase contacts (H-2-96422, zone 6F).}

Hotor starter $3 \mathrm{H}$ is energized when the steam dry air system is operating. Following a seismic event which initiates a ventilation shutdown, motor starter $3 H$ is deenergized when contact K3-1 or K4-1 opens. Deenergizing motor starter 3H opens 480 volt, 3 phase contacts, which deenergizes the steam dry air, $15 \mathrm{HP}$, stage 2 process fan.

4.1.5 Undervoltage rolays for supply fan breakers 1 through 8 (H-2-78073, sheet 2, 1 ines $3,4,5$, and 6$)$.

The undervoltage relays for supply fan breakers 1 through 8 must be energized for the breakers to remain closed. Following a seisuic event which initiates a ventilation shutdown, the undervoltage relays are deenergized when contacts $k 1-1, K 2-1, K 1-2$ and $K_{2}-2$ open. Deenergizing the undervoltage relays opens the associated supply fan breakers due to spring pressure actuating the tripper bars.

4.1.6 Supply fan broakers for fans 51 through 58 .

The supply fan breakers for fans $\$ 1$ through $\$ 8$ provide electrical power to the supply fans when the breakers are closed. Following a seismic event which initiates a ventilation shutdown, the supply fan breakers are opened, deenergizing supply fans SI through S8, when the undervoltage relay for each breaker is deenergized.

4.1.7 Accelerometor 1 and 2 "on-line/bypass" switches (H-2-78073, sheet 2, Iines 52, 58; H-2-96401 sheet 2) and assoclated wiring.

The accelerometer 1 and 2 "on- 7 ine/bypass" switches allow the accelerometers to be tested while preventing relays $\mathrm{Kl}$, K2, K3 and $K_{4}$ from being deenergized. Additional contacts on the "on-line/bypass" switches activate the "seismic fan shutdown system disabled" power control room annunciator window when both switches are placed in the bypass position. This latter function alerts plant personnel that the seismic fan shutdown systen is not OPERABLE and justifies the inclusion of the switches and their associated wiring in the safety envelope.

This equipment is not required to function following a seismic event and therefore does not need to be seismically qual ified. 


\subsubsection{Seismic fan shutdown systom disabled Power Control Room} Annunciator (ANH-714 window 30[15B]).

The seismic fan shutdown system disabled power control room annunciator (ANH-714 window 30[158]) is activated when both accelerometer 1 and 2 "on-l ine/bypass" switches have been placed in the bypass position. This alerts plant personnel that the seismic fan shutdown system is not OPERABLE. This justifies the inclusion of the annunciator in the safety envelope.

This equipment is not required to function following a seismic event and therefore does not need to be seismically qualified.

\subsection{JUSTIFICATION FOR EXCLUSION OF EQUIPMENT FROM SE}

The components excluded from the safety envelope are not required to operate to satisfy WHC-SD-CP-OSR-010, LCO 3.2.3.

Specific components not included in the safety envelope and the reasoning behind their exclusion is discussed below.

\subsubsection{VAC dedicated seismic shutdown uninterruptable power} supply (UPS).

The seismic shutdown UPS is not included in the safety envelope because the seismic shutdown system utilizes a "fail-safe" design in which power is required to keep the fans operating. The selsaic shutdown UPS is not required to ensure the shutdown of the 234-5Z supply fans and the dry air stage 2 process supply fans in the event of an earthquake greater than or equal to $0.07 \mathrm{~g}$. If the UPS power is lost, the seismic fan shutdown system will operate to deenergize the supply fans, as required. While an inadvertent loss of the seismic shutdown UPS and the resultant loss of ventilation in the facility will interrupt plant operations, this does not Justify its inclusion in the safety envelope. 
4.2.2 Solsmic status and corridor 14 soismic fan shutdown system disabled horns and larm light.

The seismic status provides individual accelerometer bypass alarms, seisuic detectors on line indication, seismic alarms, UPS avallable indication, and power available indication. None of the above alarms or indications are required to function to ensure that the seismic fan shutdown system operates properly or to alert personnel of the system's inability to operate properly. The corridor 14 seismic fan shutdown disabled horn and alarm light provides notification to personnel working on the system that the system is disabled. The primary safety class indication is provided separately by Power Control Roow Annunciator (ANN714). Therefore none of seismic status panel indications, alarms or components discussed above are included in the safety envelope.

4.2.3 Relays KES-5, KES-9, KES-10, and KES-13 and their associated contacts.

Relays KES-5, KES-9, KES-10 and KES-13 and their associated contacts function to shut down the 234-5Z exhaust fans following a $0.07 \mathrm{~g}$ earthquake. The exhaust fans are not a safety concern since the fans cannot cause a pressurization of the building. As noted in section 2.0, pressurization of the bullding as the result of an earthquake is the safety concern that this system mitigates. Therefore, relays KES-5, KES-9, KES-10 and KES-13 and their associated contacts are not included in the safety envelope.

4.2.4 Relays KES-1, KES-4 and KES-6 and their associated contacts.

Relays KES-4 and KES-6 and the ir associated contacts function to shut down the electric and steam stage 1 process supply fans, filter fram supply fan $(S-10)$ and the air conditioning supply fan to the inspection area (S-11) following a $0.07 \mathrm{~g}$ earthquake.

The stage 1 process fans for the electric and steam dry air systems are 2 horsepower fans. The fans move air through the first drying stage of the air dryers. The stage 2, 15 horsepower fans (see 4.1.3 and 4.1.4) provide the motive force to supply air to the gloveboxes. Without the stage 2 fans operating, the stage 1 fans do not have the capacity to move a large volume of air to the gloveboxes. Thus the stage 1 fans will not cause significant release of radioactive material following a seismic event.

Fan S-10 is driven by a horsepower wotor. When in service, it uses air from Zone 1 to pressurize an annular 
space around each Zone 3 and Zone 4 filter in the final fliter rooms. This prevents leakage during normal operation even if a filter gasket fails to seal. It does not provide any mechanism for a significant release after a seismic event.

Fan S-11 is driven by another small motor, and while it provides air to the Zone $3 A$ inspection area, it is not fed from the supply plenum unless an adequate differential pressure is maintained in Zone $3 \mathrm{~A}$. If the pressure differential is lost and the fan continues to operate, any air that S-11 moves will come from the same zone. In view of the flow path and the volume of air moved by this fan, will not cause a significant release of radioactive material following a seismic event.

For these reasons, relays KES-4 and KES- 6 and their associated contacts are not included in the safety envelope.

4.2.5 Relays KES-7, KES-11, and timing module KTD-8 and their assoclated contacts.

Relays KES-7, KES-11, and timing module KTD-8 and their associated contacts function to delay the shutdown of the exhaust fans for about 20 seconds after the supply fans have been shutdown by the seismic fan shutdown system. The shutdown of the exhaust fans is not a safety concern since the fans cannot cause a pressurization of the building. As noted in section 2.0, pressurization of the building as the result of an earthquake is the safety concern that this system mitigates. Therefore relays KES-7, KES-11, and timing module KTD-8 and their associated relays are not included in the safety envelope.

4.2.6 The wiring and Junction boxes which connect safety envelope components.

The wiring and junction boxes which connect the seismic shutdown control panels, seismic status panel, undervoltage relays for supply fans $S 1$ through 58 , and the electric and steam air dryer starter cabinets are excluded from the safety envelope because the seismic shutdown system utilizes a "fall-safe" design in which power is required to keep the fans operating. The continuity of connecting wiring is not required to ensure the shutdown of the 234-5Z supply fans and the dry air process supply fans in the event of a $0.07 \mathrm{~g}$ earthquake. If any of the connecting wiring in a conduit is severed or shorted together, the seismic fan shutdown system will operate to deenergize the required supply fans. While an inadvertent break in this wiring and the resultant loss of ventilation in the facility will interrupt plant operations, this is not justification for including the 
seismic shutdown systems connecting wiring in the safoty envelope. Associated wiring identified in Section 4.1.13 is excluded from this section since the wiring is required to alert operators when the seisaic shutdown system is not OPERABLE. Therefore, the wiring addressed in Section 4.1.13 is included in the safety envelope.

\subsection{SAFETY ENVELOPE PROCEDURES}

The following procedures and practices are required to ensure compliance with LCO 3.2.3 is achieved during all MODES. The procedures include operating procedures, alarm response procedures and aintenance procedures. Each procedure included in the Safety Envelope and the justification for its inclusion is presented below.

\subsection{SE ALARH RESPONSE PROCEDURE}

\subsubsection{ZAR-001, AW-714 Panel Alarms}

This procedure provides instructions for responding to the seismic system disabled alarm.

\subsection{EQUIPHENT MAINTEMANCE ND REPAIR}

In house repair or attempted repair of the Safety Class equipment except for the supply fan circuit breakers is not permitted. Repair of supply fan circuit breakers is perwitted if followed by satisfactory performance of 2SE-12A-001 or ZSE-12A-002. Other Safety Class equipment or parts within the equipment may only be replaced with like equipment or parts by in house work forces.

\subsection{SAFETY ENELOPE SURYEILLANCE REQUIREMENTS}

\subsection{SURVEILLANCE REQUIREMENT SR 3.2.3.1}

OSR Surveillance Requirement SR 3.2.3.1 requires an annual FUNCTIONAL TEST of the accelerometer activated supply ventilation system seismic shutdown system. This test is performed by procedure ZSE-99B-001, "Annual Seismic Shutdown System In-Service-Test." To satisfy this requiranent the procedure must exercise every component in the system from the accelerometers to the supply fan circuit breakers. The procedure must verify that a signal from either accelerometer results in a trip signal to each supply fan wotor controller and that each motor controller interrupts power to its motor on receipt of a trip signal. ZSE-12A-001 and ZSE-12A-002 perform an annual test of the supply fan breakers undervoltage (UV) trip to ensure a loss of voltage to the undervoltage relay will open the circuit breaker. 


\subsection{SURVEILLNCE REQUIREMENT SR 3.2 .3 .2}

OSR Surveillance Requirement SR 3.2 .3 .2 requires an annual calibration of each accelerometer channel. This calibration is perforwed by procedure 25E-998-002, "Annual Functional Test of Terra Technology Accelerometers." To satisfy the surveillance requirement, this procedure verifies the calibration of the accelerometer to ensure it provides a trip signal when stimulated by a force equivalent to a $0.07 \mathrm{~g}$ seismic event. If an accelerometer is found to be out of calibration, it is sent back to the manufacturer for calibration.

\section{REFERENCES}

Rev 0, January 1995, Plutonium Finishing Plant Final Safety Analysis Report, WHC-SD-CP-SAR-021.

Plutonium Finishing Plant Operational Safety Requirements, WHC-SD-CP-OSR-010, Rev 0, May 1994

Operating Procedure, ZAR-001, ANN-714 Panel Alarms

Maintenance Procedure, ZSE-99B-001, Annual Seismic Shutdown System In-Service Test.

Maintenance Procedure, ZSE-99B-002, Annual Functional Test of Terra Technology Accelerometer.

Maintenance Procedure, ZSE-12A-001, Annual Inspection and Testing Electrical Switchgear Breakers for Supply Fans SF-1 through SF-4

Maintenance Procedure, ZSE-12A-002, Annual Inspection and Testing Electrical Switchgear Breakers for Supply Fans SF-5 through SF-8

PFP Safety Equipment List, WHC-SD-CP-TI-108.

Design Criteria PFP Seismic Fan Shutdown System, WHC-SD-CP-CR-028 Rev. 2A, December 12, 1989. 
Appendix A - OSR Systems Compliance Sheet

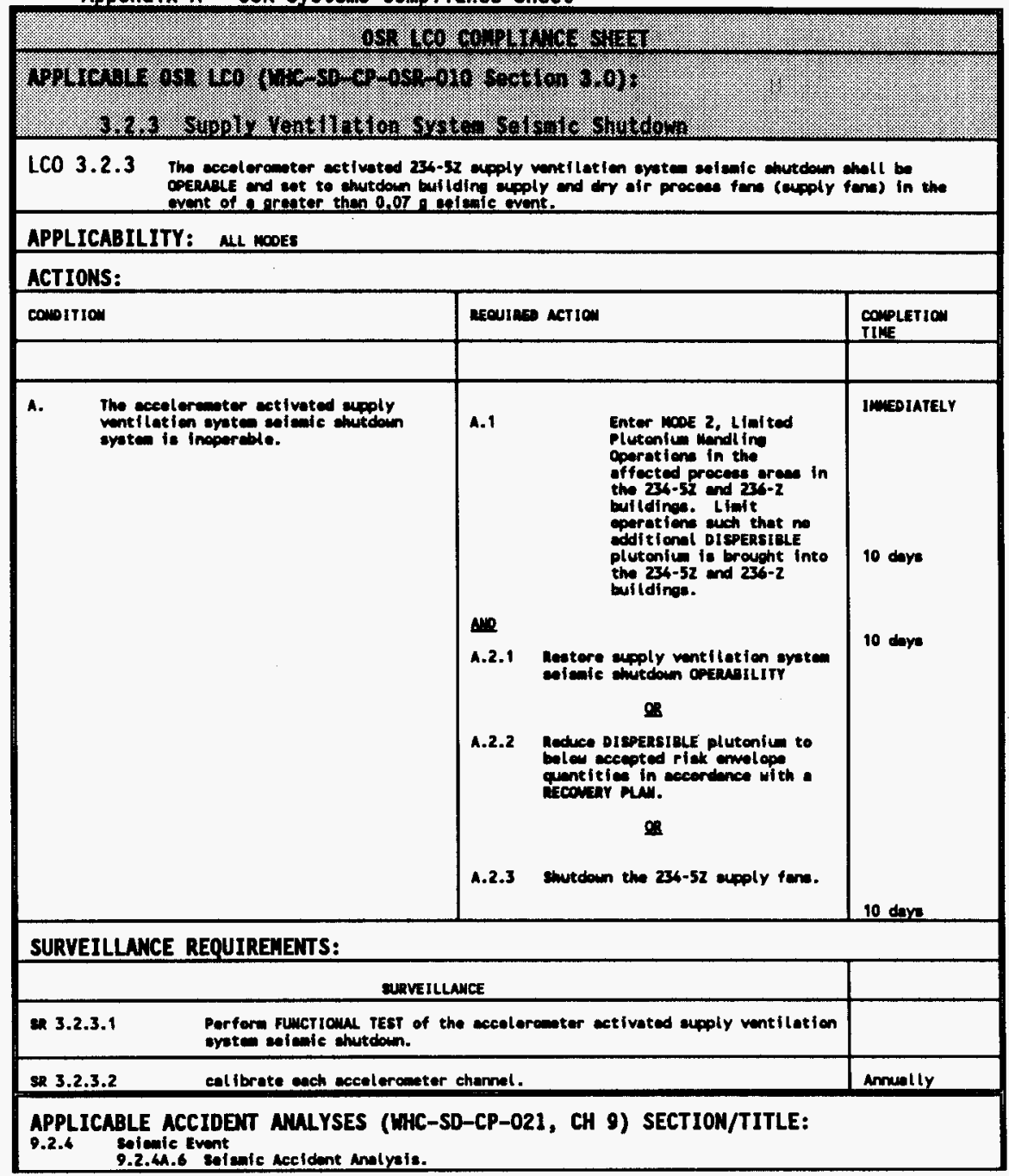




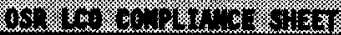

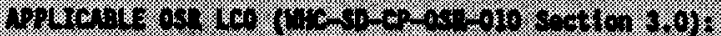

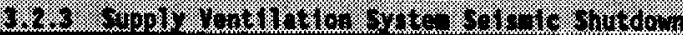

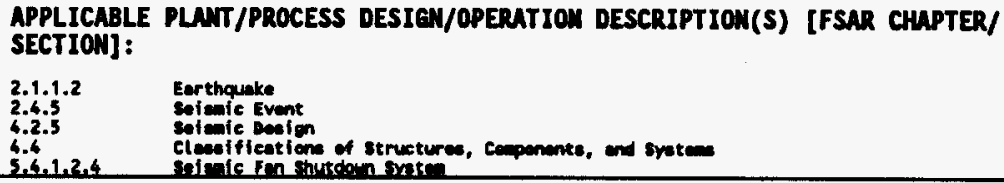

2.1.1.2

2.4 .5

4.2 .5

4.6

$5,6,1,2,4$

Earthquake

seisuic Event

Solemic berion

Cleadifications of structures, Copenents, and syetene

BOUNDARY IDENTIFICATIOM DRAMINGS:

H-2-7807, sheet 2, seisule shutdoun syeten, electrical

H-2-16318, wheot 1, fen Control sohnet ic and Cemtrol Penel

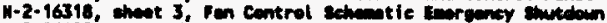

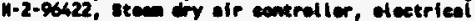

M-2-96436, sheot 4, Etectrie dry alf eenkroller, electrieal

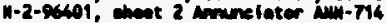

\section{SYSTEN DRAWINGS:}

H-2-78073, sheet 2, Solcaic suntdoun oveten, electrical

H-2-16318, sheot 1. Fen Centpol schemetic in centrol Panal

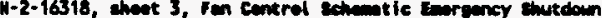

H-2-96422, stem dry olr centroller, electrical

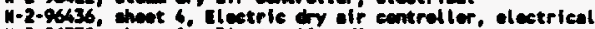

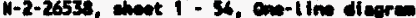

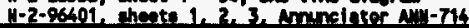

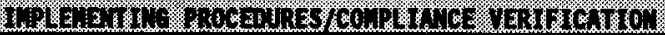

\section{OPERATING:}

218-001, AWN-714 Pencl Alerns

20-060-811, Alarn Reapones for seisuie Penel Alarm

20-060-117, Aorform Power Equipment survillience

20-060-119, Porform Earoncy sutedoun of Ventilation spotem

20-060-102, stertup/shutdown Vent llat ien swetem.

20-100-600, Perfor Mucleer goeretion survefllence end Respenses

LABORATORY: None

HEALTH PHYSICS: Mone

OPERATING SPECIFICATION(S): None

ADHINISTRATIVE: Mone

MAINTENANCE: None

SURVEILLANCE REQUIREMENTS

s.2.3.1

\begin{tabular}{|l|}
\hline PROCEDURE MUNBER \\
\hline $25 E-998-001$ \\
\hline $25 E-124-001$ \\
\hline
\end{tabular}

\begin{tabular}{|c|c|}
\hline DESCRIPTION & $\begin{array}{l}\text { PROCEDURE } \\
\text { FREQUENCY }\end{array}$ \\
\hline Inctional teits & Annual \\
\hline $\begin{array}{l}\text { Electricel ewitchower breaker functional } \\
\text { test, Sfe } 1 \text { through } 4\end{array}$ & Amrual \\
\hline
\end{tabular}




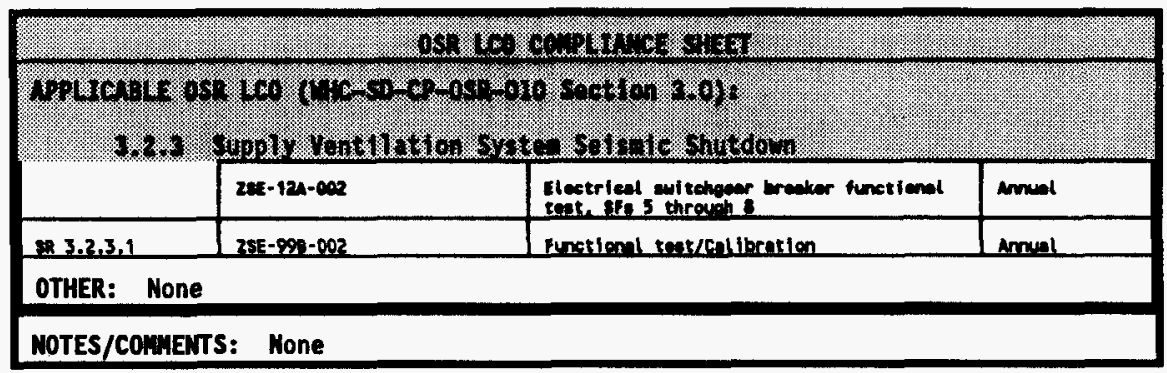




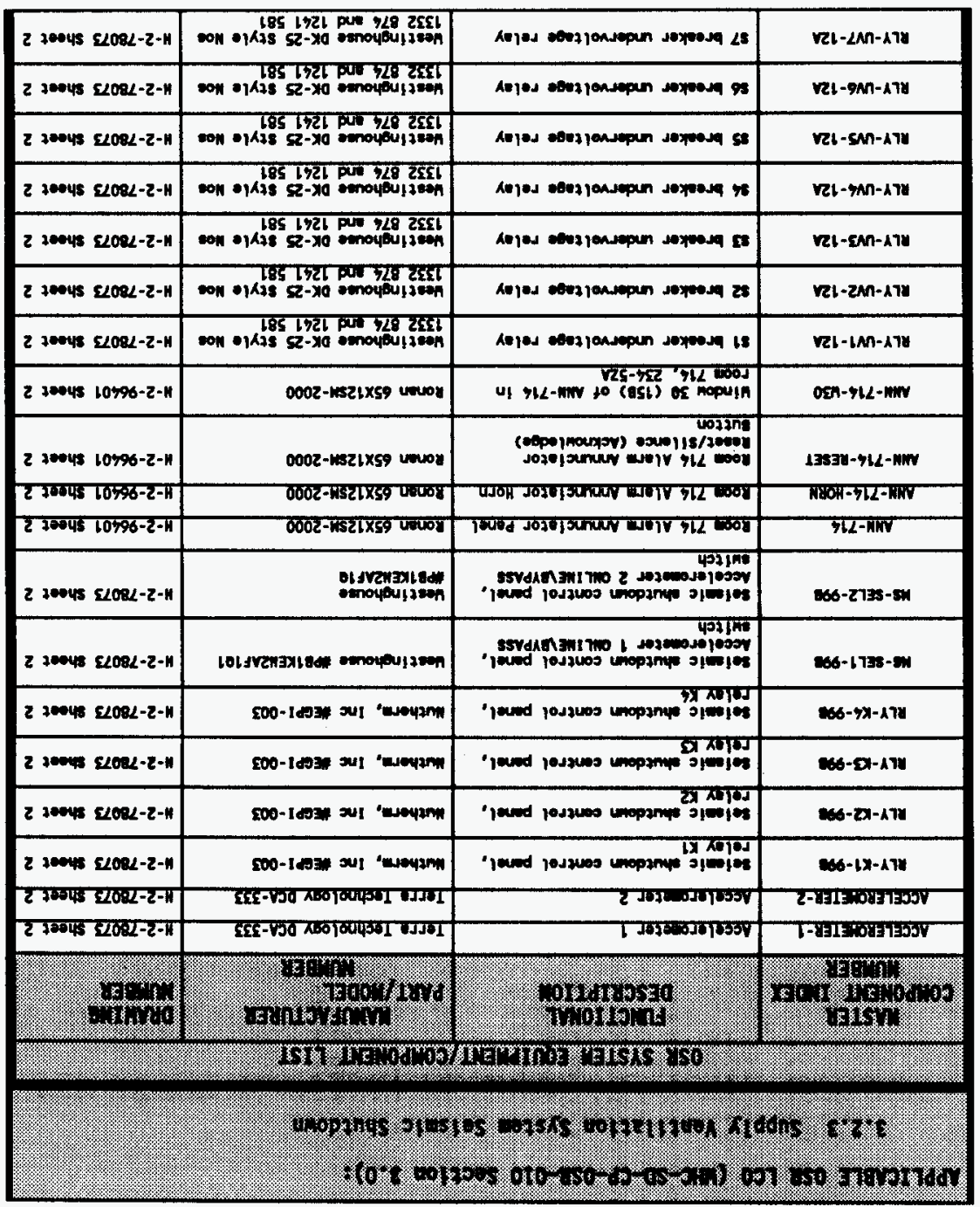

75.7 znduI xapuI quauodwog dazsey - 8 x/puaddy

LI to 9I abed

$b \cdot$ a

to0-00S-dJ-0S-JHA

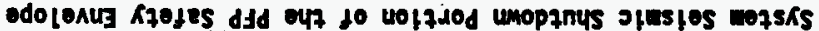

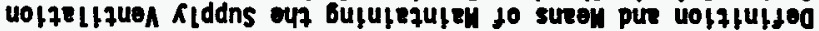




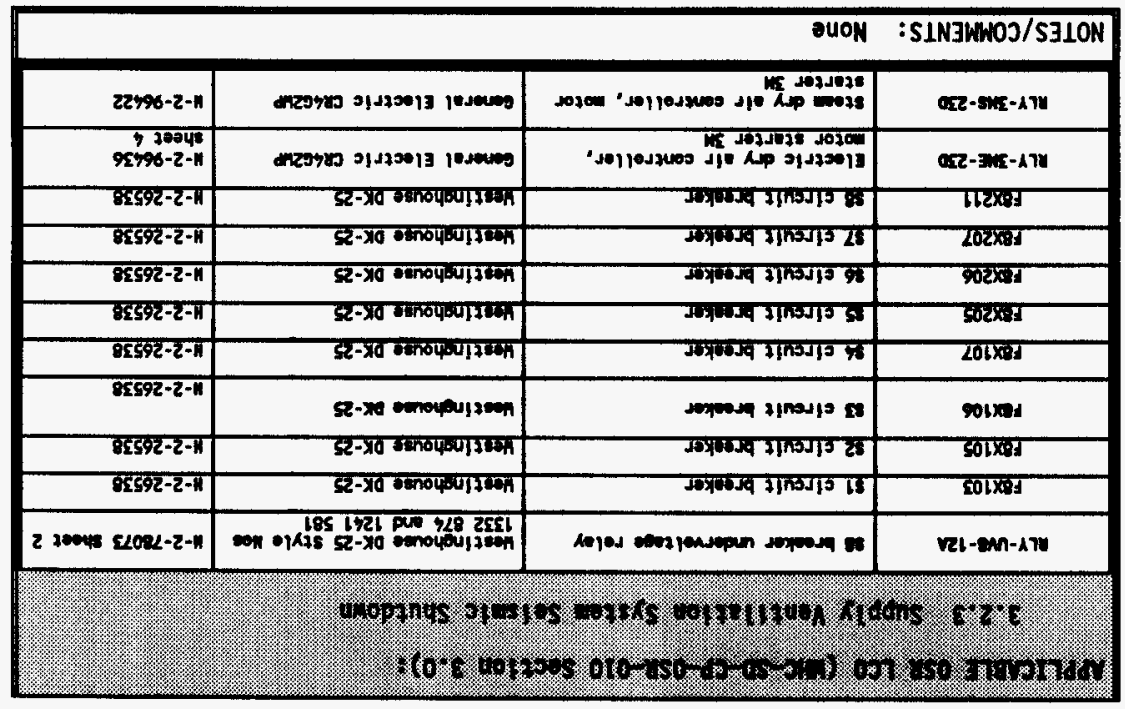

LI fo LI כobed $\rightarrow$ hay

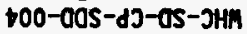

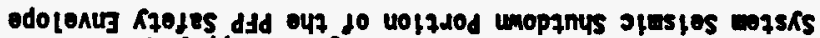

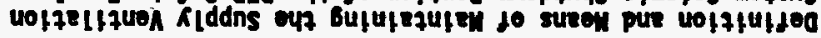

